\title{
Technical and Economic Analysis of Net Energy Metering for Residential House
}

\author{
T. M. N. T. Mansur ${ }^{1}$, N. H. Baharudin ${ }^{2}$, R. Ali $^{3}$ \\ ${ }^{1,2,3}$ School of Electrical System Engineering, Universiti Malaysia Perlis, 02600 Arau, Perlis, Malaysia \\ ${ }^{1}$ Centre of Excellence for Renewable Energy (CERE), Universiti Malaysia Perlis, 02600 Arau, Perlis, Malaysia
}

\begin{tabular}{l}
\hline \hline Article Info \\
\hline Article history: \\
Received Feb 1, 2018 \\
Revised Apr 21, 2018 \\
Accepted Apr 27, 2018 \\
\hline
\end{tabular}

Keywords:

Solar PV

Residential House

Net Energy Metering

PVsyst

Renewable Energy

\begin{abstract}
Renewable Energy Act (RE Act) has been gazetted by the Malaysian Government in 2011 to encourage energy generation from renewable resources. Under Feed-in Tariff (FiT) scheme, solar PV has gained popularity due to its high FiT rates. However, the FiT scheme for solar PV has expired in 2016 and been replaced by the Net Energy Metering (NEM) scheme. The objective of this research work is to technically and economically analyze the solar PV system for a residential house under NEM scheme. The methodology involves gathering solar energy resource information and daily residential load profile, sizing PV array together with grid-connected inverter and then lastly simulation of the design system by using PVsyst software. Based on the results obtained, the amount of energy generated is higher when the capacity of solar PV system is increased. While most of the energy generated is exported to the grid, only up to $25 \%$ of load demand is supplied by the solar PV system. From economic aspect, the residential house does not need to pay the electricity bill due to the selfconsumed of energy generated and profit gained from excess energy exported to the grid. From the environmental aspect, 2,434 kWh energy generated from renewable resource annually and consumed by the residential load has replaced the fossil fuel based power from grid. This value is equivalent to almost 1.7 tons of $\mathrm{CO}_{2}$ avoidance to the environment.
\end{abstract}

Copyright $(0) 2018$ Institute of Advanced Engineering and Science. All rights reserved.

\section{Corresponding Author:}

\author{
T. M. N. T. Mansur
}

School of Electrical System Engineering,

Universiti Malaysia Perlis, 02600 Arau, Perlis, Malaysia.

Email: tunkunizar@unimap.edu.my

\section{INTRODUCTION}

The Government of Malaysia has gazetted Renewable Energy Act (RE Act) in 2011 together with the Sustainable Energy Development Authority Act (SEDA Act) to encourage energy generation from renewable resources in Malaysia. This is in line with government's inspiration to reduce dependency on fossil fuel based energy resources such as natural gas and coal that has been used mostly as the source of electricity generation [1]. In addition, the use of renewable energy will reduced greenhouse gas emissions to the environment that cause global warming consistent with Malaysia's commitment to the World during the 15th Conference of the Parties (COP15) under the United Nations Framework Convention on Climate Change (UNFCCC) at Copenhagen in 2009.

Through RE Act 2011, the Feed-in Tariff (FiT) scheme was introduced to promote energy generation from renewable energy resources up to $30 \mathrm{MW}$. Four potential resources covered under FiT scheme are solar PV, biomass, biogas and small hydroelectric. Through FiT scheme, each kWh of energy generated from these renewable resources will be sold to the grid at a fixed rate for contractual period of 21 years [2]. Among these four, solar PV is the most popular and has the highest demand due to its high FiT rates compared to others. However, the FiT scheme for solar PV has expired in 2016, and been replaced by 
the Net Energy Metering (NEM) scheme. This NEM scheme is different from the former scheme in which the energy produced from the solar PV system will be consumed first by the loads, and any excess energy is exported and sold to the grid at a predetermined rate which is RM 0.31 per $\mathrm{kWh}$ for residential customers (low voltage connection point) and RM 0.23 per $\mathrm{kWh}$ for commercial and industrial customers (medium voltage connection point) [3]. By generating their own clean energy from renewable resources, consumers could contribute to reduce the impact of environmental pollution generated by fossil fuels [4]. According to SEDA portal, the baseline $\mathrm{CO}_{2}$ for electricity generation for Peninsular of Malaysia is $0.694 \mathrm{tCO} / \mathrm{MWh}$ in 2014 [5]. Figure 1 shows basic block diagram comparing between FiT and NEM connection to grid through low voltage connection point.

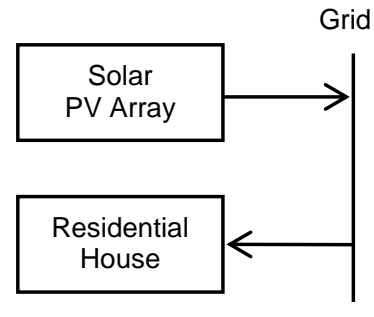

(a)

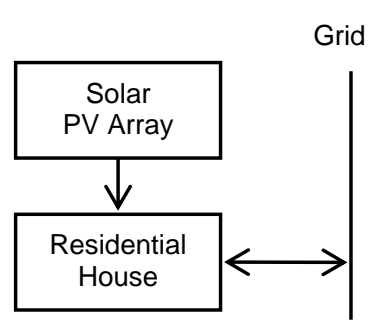

(b)

Figure 1. Basic block diagram for (a) solar PV FiT connection to grid and (b) solar PV NEM connection to grid

Up to date, various studies have been conducted to evaluate the performance of solar PV system for both FiT and NEM schemes. For example, a comparative study on FiT and NEM implementation at university building was performed by Tan 2016 where he concluded that the FiT scheme have shorter return of investment years while NEM scheme will reduced maximum demand and overall loads consumption of the campus [6]. Another study has divided the residential by three categories which are low, medium and high energy demands. The conclusion was that NEM implementation is favourable and economically viable for high energy consumers [7]. Another study done by Dellosa 2015 on the impact NEM implementation on daily load profile and its economic aspect has shown that the grid's load demand were significantly reduced during daytime. Although the computed payback period was considered long, it was worthwhile considering the long operating life of the PV systems [8].

\section{METHODOLOGY}

In this research, a solar PV system under NEM scheme for residential house is designed and investigated for both technical and economic aspects. The methodology involves gathering solar energy resource information and daily residential load profile, sizing PV array together with grid-connected inverter and then lastly simulation of the design system by using PVsyst software.

\subsection{Solar Energy Resource}

In this research work, Changlun $\left(6.44{ }^{\circ} \mathrm{N}, 100.43{ }^{\circ} \mathrm{E}\right)$ which is located at the northern of Peninsular Malaysia has been chosen as the project site. Information on solar energy is obtained from Meteonorm 7.1 that provided monthly meteorological data which has been preloaded in PVsyst software. The PV array plane is set at tilt angle of $15^{\circ}$ facing South as shown in Figure 2. The monthly global solar irradiation and average daily ambient temperature for is shown in Figure 3. The annual global solar irradiation is $1,798 \mathrm{kWh} / \mathrm{m}^{2}$. March has highest irradiation which is $178.0 \mathrm{kWh} / \mathrm{m}^{2}$ while December has the lowest irradiation which is $121.6 \mathrm{kWh} / \mathrm{m}^{2}$. Moreover, the annual average daily ambient temperature is $27.4{ }^{\circ} \mathrm{C}$ with May has the highest which is $28.1^{\circ} \mathrm{C}$ while November has the lowest which is $26.5^{\circ} \mathrm{C}$. 

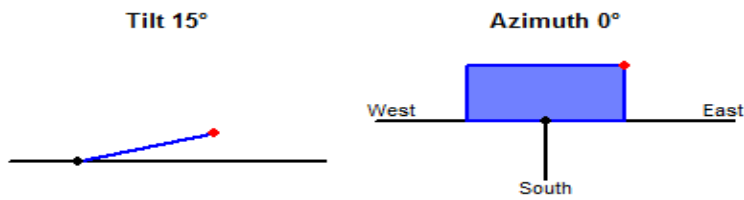

Figure 2. Tilt angle and azimuth angle of PV array plane

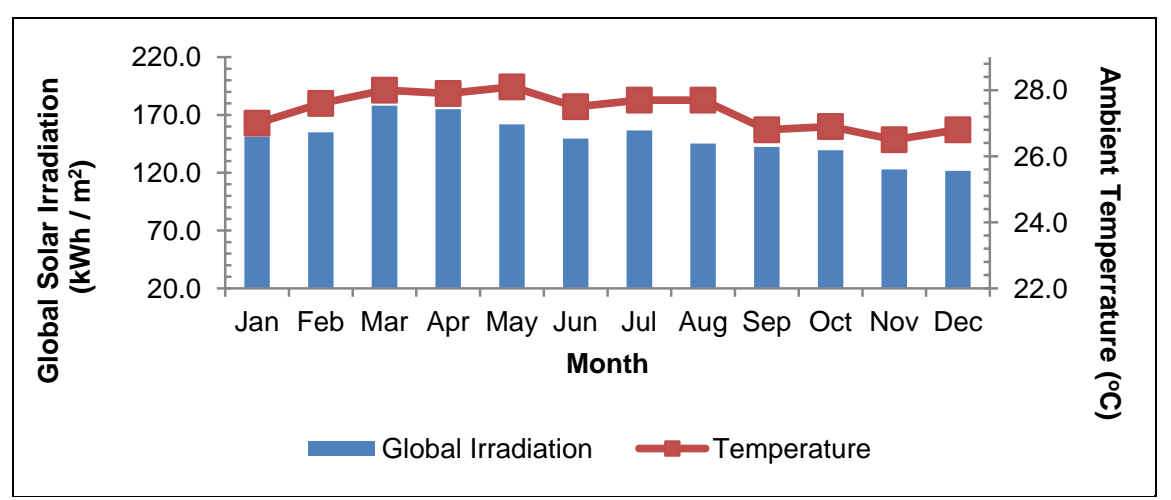

Figure 3. Monthly global solar irradiation and average daily ambient temperature for Changlun, Malaysia

\subsection{Residential Load Profile}

One of the important aspect before deciding to implement NEM for residential house is the information regarding the energy usage by the residents so that the energy generated from the PV array could be self-consumed by the loads first before exporting to the grid. Without NEM implementation, the energy used by the loads is totally supplied from the grid. However, with the implementation of NEM, some portion of the load's demand will be met by the solar PV system which will result in a reduction in electricity bills. Generally, a residential house will consist of basic electrical appliances such as lightings, fans, phone's charger, television, washing machine and refrigerator. The usage of these appliances is according to the lifestyles of residents [9].

A study has been made to obtain an hourly load profile for a residential house, where a power monitoring device has been installed to monitor power consumption for a week at several houses in Changlun that used in average $200 \mathrm{kWh}$ per month [10]. The electricity tariff rate for those who used electricity in this range is RM 0.218 per $\mathrm{kWh}$. The average daily load profile is shown in Figure 4 where the average daily consumption in $6.67 \mathrm{kWh}$ with $0.86 \mathrm{~kW}$ of peak power demands. The hourly trend shows that the high demand occurs twice a day between $6.00 \mathrm{am}$ to $9.00 \mathrm{am}$ in the morning and between $7.00 \mathrm{pm}$ until $11.00 \mathrm{pm}$ in the evening. Assuming this daily load is constant throughout a year, the total energy demand is $2,434 \mathrm{kWh}$ per year.

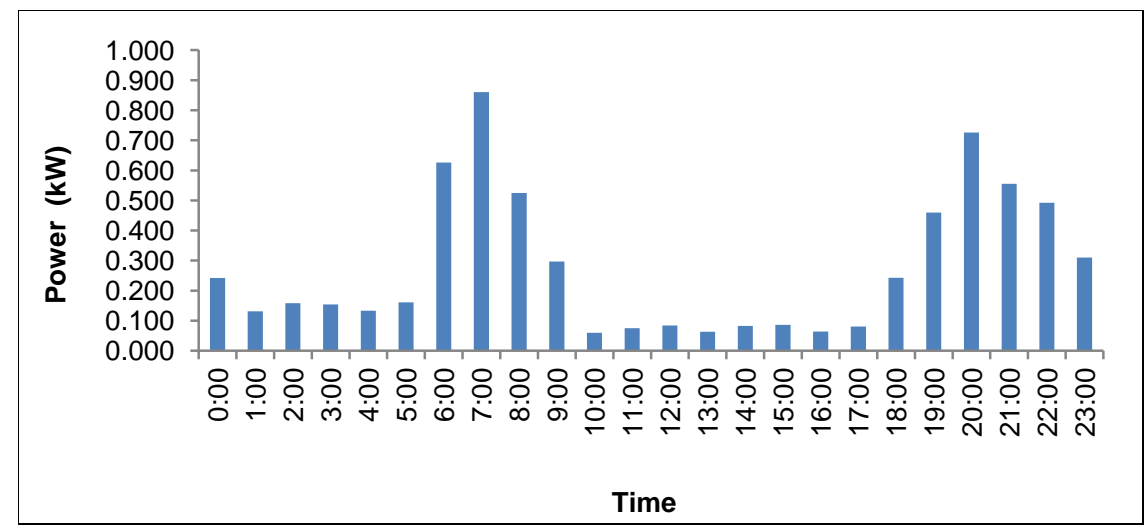

Figure 4. Average daily load profile for residential house that used $200 \mathrm{kWh}$ of energy per month 


\subsection{PV Array and Inverter Sizing}

In general, solar PV array is sized according to the desired capacity, rooftop area or available budget. The output energy of PV array is a function of peak sun shine hours and temperature. The estimation of energy generated from PV array is simplified and calculated based on Equation (1) [11].

$$
E_{\text {array }}=P_{\text {array }} \times P S H_{\text {period }} \times f_{\text {temp }}
$$

where $E_{\text {array }}$ is $\mathrm{PV}$ array yield in $\mathrm{kWh}, P S H_{\text {period }}$ is Peak Sun Hour factor and $f_{\text {temp }}$ is temperature de-rating factor. The PSH factor is obtained from solar irradiation data in previous section. The temperature de-rating factor, $f_{\text {temp }}$ is given by the Equation (2)

$$
f_{\text {temp }}=1+\left[\left(\frac{\gamma_{p m p}}{100}\right) \times\left(T_{\text {cell_ave }} \times T_{\text {stc }}\right)\right]
$$

where $\gamma_{p m p}$ is temperature coefficient for $P_{m p}$ in $\%$ per ${ }^{\circ} \mathrm{C}, T_{\text {cell_ave }} \quad$ is average daily maximum cell temperature and $T_{s t c}$ is cell temperature at standard test condition which is $25^{\circ} \mathrm{C}$. The average cell temperature, $T_{\text {cell_ave }}$ is given by Equation (3)

$$
T_{\text {cell_ave }}=T_{a m b_{-} a v e \_ \text {max }}+\left[\left(\frac{N O C T-20}{800}\right) \times G_{a m b_{-} a v e \_\max }\right]
$$

where $T_{\text {amb ave max }}$ is average daily maximum ambient temperature in ${ }^{\circ} \mathrm{C}$, NOCT is nominal operation cell temperature in ${ }^{\circ} \mathrm{C}, G_{\text {amb_ave_max }}$ is average daily maximum solar irradiance in W per $\mathrm{m}^{2}$. The Yingli Solar YL250P-29b, a $250 \mathrm{Wp}$ PV module is used in this research work. Selected module's specification which has been preloaded in the PVsyst database are shown in Table 1. Table 2 shows the PV array configuration according to their PV array capacity that will used in this research work. The series and parallel arrangement must matched with the inverter specification.

Table 1. PV Module Specification

\begin{tabular}{cc}
\hline Parameter & $\begin{array}{c}\text { Value at Standard Test Condition } \\
\text { (STC) }\end{array}$ \\
\hline Power output, $P_{\max }$ & $250.0 \mathrm{Wp}$ \\
Voltage at $P_{\max }, V_{m p p}$ & $30.23 \mathrm{~V}$ \\
Current at $P_{\max }, I_{m p p}$ & $8.27 \mathrm{~A}$ \\
Open-circuit voltage, $V_{o c}$ & $37.73 \mathrm{~V}$ \\
Short-circuit current, $I_{s c}$ & $8.83 \mathrm{~A}$ \\
Module efficiency & $15.40 \%$ \\
Temperature coefficient at $P_{\max }, \gamma_{\operatorname{mpp}}$ & $-0.42 \% /{ }^{\circ} \mathrm{C}$ \\
\hline
\end{tabular}

Table 2. PV Array Configuration

\begin{tabular}{cccc}
\hline PV Array Capacity & $\begin{array}{c}\text { Number of PV Module } \\
\text { in Series }\end{array}$ & $\begin{array}{c}\text { Number of Parallel } \\
\text { String }\end{array}$ & $\begin{array}{c}\text { Total Number of PV } \\
\text { Module Used }\end{array}$ \\
\hline $2.0 \mathrm{kWp}$ & 8 & 1 & 8 \\
$4.0 \mathrm{kWp}$ & 8 & 2 & 16 \\
$6.0 \mathrm{kWp}$ & 12 & 2 & 24 \\
$8.0 \mathrm{kWp}$ & 17 & 2 & 34 \\
$10.0 \mathrm{kWp}$ & 20 & 2 & 40 \\
$12.0 \mathrm{kWp}$ & 12 & 4 & 48 \\
\hline
\end{tabular}


Grid connected inverter is a device used to convert DC input from solar PV array to AC output. Table 3 shows list of inverter used in the simulation according to the PV array capacity together with their selected specifications which has been preloaded in the PVsyst database.

Table 3. Inverter Specification

\begin{tabular}{|c|c|c|c|c|c|c|}
\hline $\begin{array}{l}\text { PV Array } \\
\text { Capacity }\end{array}$ & Brand & Model & $\begin{array}{c}\text { Nominal AC } \\
\text { Power }\end{array}$ & $\begin{array}{c}\text { DC Input } \\
\text { Voltage } \\
\text { Range }\end{array}$ & $\begin{array}{c}\text { AC Output } \\
\text { Voltage }\end{array}$ & $\begin{array}{l}\text { Maximum } \\
\text { Efficiency }\end{array}$ \\
\hline $2.0 \mathrm{kWp}$ & $\mathrm{ABB}$ & UNO-2.0-I-OUTD & $2.0 \mathrm{~kW}$ & $90-520 \mathrm{~V}$ & $\begin{array}{c}230 \mathrm{~V} \text { - Single } \\
\text { Phase }\end{array}$ & $96.2 \%$ \\
\hline $4.0 \mathrm{kWp}$ & $\mathrm{ABB}$ & UNO-DM-4.0-TL-PLUS & $4.0 \mathrm{~kW}$ & $90-580 \mathrm{~V}$ & $\begin{array}{c}230 \mathrm{~V} \text { - Single } \\
\text { Phase }\end{array}$ & $97.0 \%$ \\
\hline $6.0 \mathrm{kWp}$ & $\mathrm{ABB}$ & PVI-6000-TL-OUTD & $6.0 \mathrm{~kW}$ & $90-580 \mathrm{~V}$ & $\begin{array}{c}230 \mathrm{~V} \text { - Single } \\
\text { Phase }\end{array}$ & $97.0 \%$ \\
\hline $8.0 \mathrm{kWp}$ & $\mathrm{ABB}$ & TRIO-8.5-TL-OUTD-400 & $8.5 \mathrm{~kW}$ & $175-950 \mathrm{~V}$ & $\begin{array}{c}400 \mathrm{~V} \text { - Three } \\
\text { Phase }\end{array}$ & $98.1 \%$ \\
\hline $10.0 \mathrm{kWp}$ & $\mathrm{ABB}$ & PVI-10.0-TL-OUTD & $10.0 \mathrm{~kW}$ & $175-850 \mathrm{~V}$ & $\begin{array}{c}400 \mathrm{~V} \text { - Three } \\
\text { Phase }\end{array}$ & $97.6 \%$ \\
\hline $12.0 \mathrm{kWp}$ & $\mathrm{ABB}$ & PVI-6000-TL-OUTD & $\begin{array}{c}6.0 \mathrm{~kW} \\
(2 \text { units) }\end{array}$ & $90-580 \mathrm{~V}$ & $\begin{array}{c}230 \mathrm{~V} \text { - Single } \\
\text { Phase }\end{array}$ & $97.0 \%$ \\
\hline
\end{tabular}

\subsection{PVSyst Simulation}

PVSyst professional software package has been developed at the University of Geneva for study, simulation, and design of PV systems [12]. PVSYST is mostly used for studying, sizing and performance analysis of photovoltaic stand alone, grid connected and water pumping systems [13]. It has a large database of meteorological data sources that available all over the world [14]. Figure 5 shows the PVsyst schematic diagram for NEM configuration.

Many researchers used PVsyst to design and simulate the performance of their PV systems either grid-connected or standalone systems by using PVsyst. For example, PVsyst software has been used to model and evaluate the energy performance of 15MW grid connected PV system. The research work also includes analyzing the performance ratio and the different losses that occur in the system [15]. In addition, Kumar 2017 has carried out study on $100 \mathrm{kWp}$ grid connected PV system using PVsyst to evaluate the feasibility of installing a PV system for supplying the electric load of an educational institute [16]. Another study was conducted by using PVsyst to evaluate the technical, economic and environmental aspects of PV system for supplying of household electricity energy needs [17].

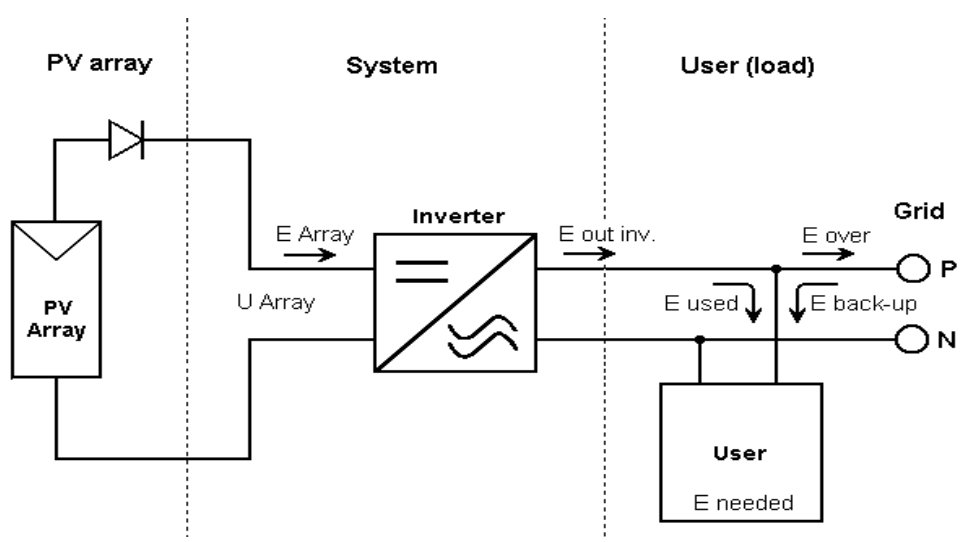

Figure 5. PVsyst schematic diagram for NEM configuration

\section{RESULTS AND ANALYSIS}

Initially, a $2.0 \mathrm{kWp}$ solar PV system for NEM is designed simulated by using PVsyst and the results are summarized in Table 4. The annual amount of energy available from the system at the inverter output is $2804.4 \mathrm{kWh}$ where $457.0 \mathrm{kWh}(16.3 \%)$ has been utilized by the load while $2347.4 \mathrm{kWh}(83.7 \%)$ has been exported to the grid. Looking from the demand side, the amount of energy required annually by the load is 
$2434.2 \mathrm{kWh}$. Most of it was met by the grid supply which is $1977.2 \mathrm{kWh}(81.2 \%)$ while only $457.0 \mathrm{kWh}$ $(18.8 \%)$ is supplied by the solar PV system.

Table 4. Balance and Result of $2.0 \mathrm{kWp} \mathrm{NEM}$

\begin{tabular}{cccccccc}
\hline Month & $\begin{array}{c}\text { GlobHor } \\
\left(\mathrm{kWh} / \mathrm{m}^{2}\right)\end{array}$ & $\begin{array}{c}\text { GlobEff } \\
\left(\mathrm{kWh} / \mathrm{m}^{2}\right)\end{array}$ & $\begin{array}{c}\text { T Amb } \\
\left({ }^{\circ} \mathrm{C}\right)\end{array}$ & $\begin{array}{c}\text { E Avail } \\
(\mathrm{kWh})\end{array}$ & $\begin{array}{c}\text { E Load } \\
(\mathrm{kWh})\end{array}$ & $\begin{array}{c}\text { E User } \\
(\mathrm{kWh})\end{array}$ & $\begin{array}{c}\text { E Grid } \\
(\mathrm{kWh})\end{array}$ \\
\hline January & 151.0 & 160.9 & 27.0 & 260.5 & 206.7 & 40.1 & 220.4 \\
February & 155.0 & 159.9 & 27.6 & 255.5 & 186.7 & 36.4 & 219.2 \\
March & 178.0 & 174.4 & 28.0 & 278.1 & 206.7 & 41.8 & 236.3 \\
April & 174.9 & 162.6 & 27.9 & 261.1 & 200.1 & 40.5 & 220.6 \\
May & 161.8 & 144.2 & 28.1 & 233.4 & 206.7 & 39.0 & 194.4 \\
June & 149.5 & 130.6 & 27.5 & 213.8 & 200.1 & 37.3 & 176.5 \\
July & 156.6 & 137.3 & 27.7 & 224.0 & 206.7 & 38.4 & 185.6 \\
August & 145.3 & 132.9 & 27.7 & 216.4 & 206.7 & 38.1 & 178.3 \\
September & 142.3 & 136.0 & 26.8 & 220.7 & 200.1 & 36.7 & 184.0 \\
October & 139.5 & 139.8 & 26.9 & 226.2 & 206.7 & 38.9 & 187.3 \\
November & 122.8 & 127.1 & 26.5 & 206.3 & 200.1 & 35.0 & 171.2 \\
December & 121.6 & 129.5 & 26.8 & 208.5 & 206.7 & 34.9 & 173.6 \\
Year & 1798.4 & 1735.2 & 27.4 & 2804.4 & 2434.2 & 457.0 & 2347.4 \\
\hline
\end{tabular}

Next, larger solar PV capacities which are $4.0 \mathrm{kWp}, 6.0 \mathrm{kWp}, 8.0 \mathrm{kWp}, 10.0 \mathrm{kWp}$ and $12.0 \mathrm{kWp}$ are designed and simulated by using PVsyst with the same residential load. The results are shown in Table 5. In general, the higher solar PV capacity will increase the energy available at the inverter output. However most of energy generated will be exported to the grid. As shown in Figure 6, the percentage of solar fraction, which is the ratio between solar energy supplied to the load and total energy demand by the load, is just approaching $25 \%$ eventhough the solar PV capacity is increased. This is due to the load demand which is high during night time, in contrast to the peak sunshine which is maximum during the daytime as shown in Figure 7.

From the economic aspect, without NEM implementation the residential house needs to pay electricity bill at retail price for more than RM 500 per annum. However, by implementing NEM, the residential house does not need to pay the electricity bill due to the self-consumed of energy generated from solar PV system and profit gained from excess energy exported to the grid. In addition, the unused profit from exported energy could be carried forward and accumulated as credit in electricity bill up to two years. As shown in Figure 8, a lot of credit will accumulated as a result of exporting energy from higher solar PV capacity. Unfortunately, the drawback of NEM scheme is the credit accumulated will expire after two years if not been used.

Table 5. Balance and Result of Different Sizing Capacity for NEM

\begin{tabular}{cccccc}
\hline $\begin{array}{c}\text { Sizing } \\
(\mathrm{kWp})\end{array}$ & $\begin{array}{c}\text { E Avail } \\
(\mathrm{kWh})\end{array}$ & $\begin{array}{c}\text { E Load } \\
(\mathrm{kWh})\end{array}$ & $\begin{array}{c}\text { E User } \\
(\mathrm{kWh})\end{array}$ & $\begin{array}{c}\text { E Grid } \\
(\mathrm{kWh})\end{array}$ & SolFrac \\
\hline 2 & $2,804.4$ & $2,434.2$ & 457.0 & $2,347.4$ & 0.188 \\
4 & $5,716.6$ & $2,434.2$ & 555.2 & $5,161.4$ & 0.228 \\
6 & $8,569.2$ & $2,434.2$ & 579.9 & $7,989.3$ & 0.238 \\
8 & $12,232.0$ & $2,434.2$ & 594.6 & $11,637.0$ & 0.244 \\
10 & $14,349.0$ & $2,434.2$ & 597.2 & $13,752.0$ & 0.245 \\
12 & $17,138.0$ & $2,434.2$ & 604.3 & $16,534.0$ & 0.248 \\
\hline
\end{tabular}




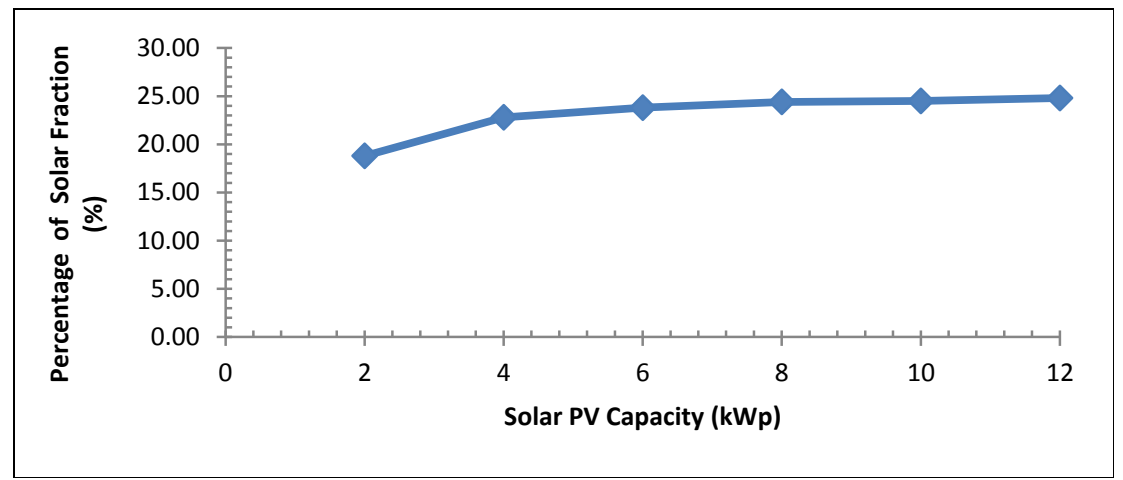

Figure 6. Percentage of Solar Fraction

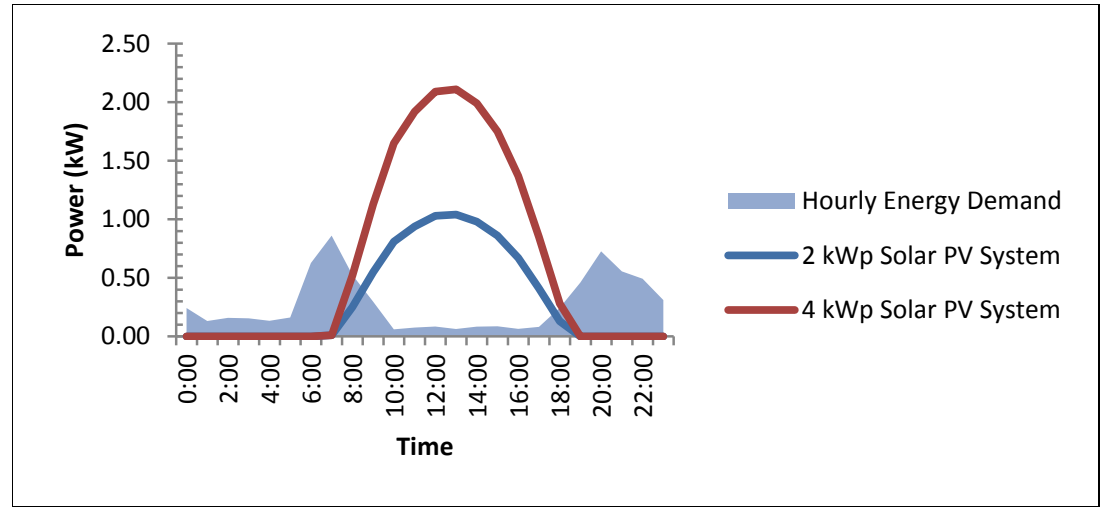

Figure 7. Average hourly energy demand and energy generated from solar PV system

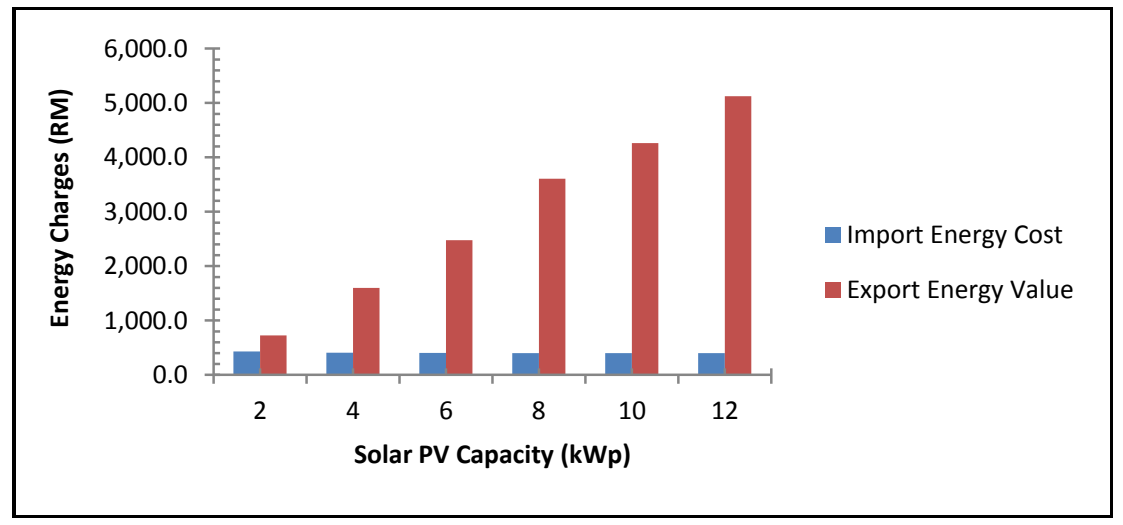

Figure 8. Comparison between Import and Export Energy Cost

In aspect of environmental conservation, 2,434 $\mathrm{kWh}$ energy generated from renewable resource annually and consumed by the residential load has replaced the fossil fuel based power from grid. This value is equivalent to almost 1.7 tons of $\mathrm{CO}_{2}$ avoidance to the environment.

\section{CONCLUSION}

Technical and economic analysis of NEM for Residential House has been presented in this paper. The analysis has been carried out by using PVsyst software simulation. Based on the results obtained, the conclusions were: 
1) From technical aspect, the annual amount of energy available from the $2.0 \mathrm{kWp}$ NEM system is 2804.4 $\mathrm{kWh}$. This amount of energy is increasing when the capacity of solar PV system is higher. Most of the energy generated is exported to the grid. Compared to amount of energy demand, only up to $25 \%$ is supplied by the solar PV system.

2) From economic aspect, by implementing NEM, the residential house no needs to pay the electricity bill due to the self-consumed of energy generated from solar PV system and profit gained from excess energy exported to the grid where the unused profit could be carried forward and accumulated as credit in electricity bill up to two years.

3) From the environmental aspect, $2,434 \mathrm{kWh}$ energy generated from renewable resource annually and consumed by the residential load has replaced the fossil fuel based power from grid. This value is equivalent to almost 1.7 tons of $\mathrm{CO}_{2}$ avoidance to the environment.

\section{REFERENCES}

[1] S. S. Abd Wahid, Z. Nawawi, M. I. Jambak, Y. Z. Arief, M. A. B. Sidik, M. W. Mustafa, and Z. Adzis, "Evaluation of Residential Grid-Connected Photovoltaic System as the Potential Energy Source in Malaysia," TELKOMNIKA (Telecommunication, Comput. Electron. Control., vol. 14, no. 4, p. 1235, 2016.

[2] S. Ahmad, R. Mat, F. Muhammad-sukki, A. Bakar, and R. Abdul, "Role of feed-in tariff policy in promoting solar photovoltaic investments in Malaysia : A system dynamics approach,” Energy, vol. 84, pp. 808-815, 2015.

[3] T. M. N. T. Mansur, N. H. Baharudin, and R. Ali, "Design of 4.0 kWp Solar PV System for Residential House under Net Energy Metering Scheme,” J. Eng. Res. Educ., vol. 9, pp. 95-106, 2017.

[4] R. Setiabudy, B. S. Hartono, and Budiyanto, "Analysis characteristics of on/offgrid tie inverter and implementation in microgrid," Telkomnika, vol. 11, no. 3, pp. 441-450, 2013.

[5] "Statistic \& Monitoring CO2 Avoidance," Sustainable Energy Development Authority (SEDA) Malaysia Portal, 2017. [Online]. Available: www.seda.gov.my.

[6] R. H. G. Tan and T. L. Chow, "A Comparative Study of Feed in Tariff and Net Metering for UCSI University North Wing Campus with 100 kW Solar Photovoltaic System," in Energy Procedia, 2016, vol. 100, pp. 86-91.

[7] M. Sahanaa Sree, S. Arunkumar, and K. K. Murugavel, "Feasibility study for the net metering implementation in residential solar PV installations across Tamil Nadu," 2014 Int. Conf. Comput. Power, Energy, Inf. Commun. ICCPEIC 2014, pp. 359-362, 2014.

[8] J. T. Dellosa, "Financial Payback of Solar PV Systems and Analysis of the Potential Impact of Net-Metering in Butuan City, Philippines," pp. 1-6, 2015.

[9] T. M. N. T. Mansur, N. H. Baharudin, and R. Ali, "Sizing and cost analysis of self-consumed solar PV DC system compared with AC system for residential house," Indones. J. Electr. Eng. Comput. Sci., vol. 10, no. 1, pp. 10-18, 2018.

[10] T. M. N. T. Mansur, N. H. Baharudin, and R. Ali, "Performance analysis of self-consumed solar PV system for a fully DC residential house," Indones. J. Electr. Eng. Comput. Sci., vol. 8, no. 2, pp. 391-398, 2017.

[11] A.M. Omar, S. Shaari, S.I. Sulaiman, Grid-Connected Photovoltaic Power Systems Design. Sustainable Energy Development Authority Malaysia, 2012.

[12] M. Bouzguenda, A. Al Omair, A. Al Naeem, M. Al-muthaffar, and O. B. Wazir, "Design of an Off-Grid 2 kW Solar PV System," pp. 1-6, 2014.

[13] V. Sharma and S. S. Chandel, "Performance analysis of a $190 \mathrm{kWp}$ grid interactive solar photovoltaic power plant in India," Energy, vol. 55, pp. 476-485, 2013.

[14] P. Yadav, "Simulation and Performance Analysis of a lkWp Photovoltaic System Using PVsyst," 2015, pp. 358363.

[15] A. Soualmia and R. Chenni, "Modeling and simulation of 15MW grid-connected photovoltaic system using PVsyst software," in Proceedings of 2016 International Renewable and Sustainable Energy Conference, IRSEC 2016, 2017, pp. 702-705.

[16] N. M. Kumar, M. R. Kumar, P. R. Rejoice, and M. Mathew, "Performance analysis of 100 kWp grid connected Sipoly photovoltaic system using PVsyst simulation tool,” Energy Procedia, vol. 117, pp. 180-189, 2017.

[17] E. Tarigan and F. Dwi, "Techno-Economic Simulation of a Grid-Connected PV System Design as Specifically Applied to Residential in Surabaya , Indonesia," Energy Procedia, vol. 65, pp. 90-99, 2015. 